University of Washington Tacoma

UW Tacoma Digital Commons

\title{
The Inclusive Family Support Model: Facilitating Openness for Post-Adoptive Families
}

\author{
JaeRan Kim \\ University of Washington Tacoma, kimjr@uw.edu \\ Angela Tucker
}

Follow this and additional works at: https://digitalcommons.tacoma.uw.edu/socialwork_pub

Part of the Social Work Commons

\section{Recommended Citation}

Kim, J., \& Tucker, A. (2019). The inclusive family support model: Facilitating openness for post-adoptive families. Child \& Family Social Work. https://doi.org/10.1111/cfs.12675 
The Inclusive Support Model: Facilitating Openness for Post-Adoptive Families

First and Corresponding Author:

JaeRan Kim, PhD., LISW

Assistant Professor, Social Work and Criminal Justice

University of Washington Tacoma

Box 358425, 1900 Commerce Street

Tacoma, WA 98402-3100

Phone: (253) 692-5623

kimjr@uw.edu

Second Author:

Angela Tucker

Director of Post-Adoption Services

Amara

5907 Martin Luther King Jr. Way South

Seattle, WA

Phone: (206) 260-1741

angela@amaraputskidsfirst.org

\section{Please cite as:}

Kim, J.R. \& Tucker, A. (2019). The Inclusive Family Support Model: A conceptual framework for working with families post adoption finalization. Child and Family Social Work.

https://doi.org/10.1111/cfs.12675

\section{Abstract}


Open adoptions have increased over the past few decades and while guidance for considering and creating open adoption agreements exist, one area of needed post-adoption support is helping adoptive and birth/first families navigate open-adoption relationships after finalization. Adoption agencies have a responsibility to assist adoptive parents, who may have fears and concerns about openness, see the potential benefits rather than only the challenges. This article describes a practice model designed by one agency to help families navigate post-adoption openness. The Inclusive Family Support model is conceptualized through the theoretical perspectives of family systems theory, ambiguous loss and disenfranchised grief, and the transtheoretical model of change. We highlight the major dimensions of the model, how it will be implemented and evaluated at one agency, and discuss implications for practice, and policy.

Keywords: adoption, open adoptions, post-adoption services, adoptive families, child welfare

\section{Introduction}


For many child welfare agencies that specialize in adoption the process of finding permanency for children is their priority; until recently fewer resources were devoted to postadoption services and support. However, the demand for such post-adoption services, including services related to assisting families navigate open adoption arrangements, is growing as adoptive families often find themselves needing professional help in meeting the needs of their adopted children (Berry, 1990; Dhami, Mandel \& Sothmann, 2007). Even if they have the desire, many agencies may not have the means to provide in-depth post-adoption services.

The move toward increased levels of openness and contact post-adoption finalization is growing in private agency facilitated adoptions. Adoptees and birth/first families increasingly express the desire to maintain some level of openness and are challenging past practices of sealed records as harmful (Feast \& Howe, 1997; Grotevant \& McRoy, 1998; Henney, McRoy, Ayers-Lopez \& Grotevant, 2003). For some birth/first families, maintaining openness is a factor in their selection of prospective parents with whom to place their child (Henney, et al., 2003). There is also a growing acknowledgement that children adopted from foster care are often adopted at an older age and many have memories and experiences with their families of origin; these children may benefit from a more open, even if limited, post-finalization relationship (Berry, 1993; Brodzinsky \& Schechter, 1990; Freundlich, Avery, Gerstenzang \& Munson, 2006; Silverstein \& Roszia, 1999; Wright, Flynn \& Welch, 2006).

As members of the adoption constellation (adoptees, birth/first parents, adoptive parents, extended family members) consider post-finalization openness between the birth/first and adoptive families, agencies are tasked with the responsibility of assisting families through the complex dynamics inherent in navigating these relationships. Oftentimes this involves helping 
adoptive parents, who may have fears and concerns about openness, see the potential benefits rather than only the challenges.

This article describes a post-adoption model developed (but not yet implemented) by one child welfare agency specifically aimed at helping adoptive families navigate open adoptions with their child's birth/first family. Both authors identify as adoptees; the first author (a social work scholar) is an intercountry adoptee with a closed adoption; the second author (the agency's post-adoption program director) had a closed adoption and has been in reunion with birth/first family since 2011. As authors immersed in the adoption field and community, we recognize the importance of language. For this article we use the term "adoption constellation" instead of "adoption triad" to acknowledge that the triad concept of adopted child, birth/first parents and adoptive parents are not inclusive enough to describe all of the people and communities included when an adoption relationship is formed. The adoption constellation expands, rather than closes, the notion of family. We also recognize that to some the term "birth parent" is problematic despite its predominant use in the adoption field; therefore, we have chosen to use "birth/first" to recognize the language preference that some birth/first parents prefer.

In this article we describe a practice model developed to assist families with opening up adoption relationships through the theoretical perspectives of family systems theory, ambiguous loss, and the transtheoretical model of change. This practice model aims to be inclusive of the voices of those most impacted by adoption services - individuals in adoptive families and birth/first families. We begin with a review of the literature, highlight the major dimensions of this practice model, discuss how it will be used, and end with a discussion of practice, policy, and research implications.

\section{Post-adoption services}


Although the adoption of children has been under the auspices of formalized child welfare care for over a century the majority of the focus has been on the front end of adoption services: the assessment and matching of children and prospective parents, matching, and oversight of the legal finalization of the adoption. Once the adoption is finalized most agencies and adoption attorneys/facilitators consider their responsibility to the family to be finished. There is a growing recognition that many families need, and desire, post-finalization support.

Post-adoption services have been found to benefit adopted children and their families (Brooks, Allen, \& Barth, 2002; Dhami et al., 2007; Smith \& Howard, 1994). Most of the literature points to the types of services that adoptive parents identify as needed or helpful including, but not limited to, mediating contact with the child's birth/first family, referrals for therapeutic and medical providers, respite, peer support (both for parents and children), financial assistance and cultural programs for their transracially adopted children (Avery, 2004; Brooks et al, 2002; Reilly \& Platz, 2004).

\section{Openness after adoption finalization}

Definitions and expectations related to post-adoption openness and contact vary. Grotevant (2000) defined levels of openness as 1) confidential/closed adoptions, in which some non-identifying information may be shared between the adoptive and birth/first families but without any contact; 2) mediated/semi-open adoption in which some information is exchanged through a third-party such as an adoption agency or adoption attorney; and 3) open/fully disclosed adoptions in which there is direct contact between the adoptive and birth/first families though this contact can vary significantly (p. 46-47). Post-finalization contact is often legally established through a written agreement typically called Contact/Communication Agreement, Open Adoption Agreement, or Open Communication Agreement, among others. 
Post-finalization contact agreements have become standard practice in private infant adoption programs and prospective adoptive parents are encouraged to agree to some level of contact with their child's birth/first family (Henney et al., 2003). Foster care adoptions have been slower to incorporate contact agreements; between $25-42 \%$ of foster care adoptions are considered open (Barbanell \& Ryan, 2006; Frasch, Brooks \& Barth, 2000).

Foster care adoptions may be less likely to be open than private adoptions because the child's placement resulted from substantiated abuse and neglect (Faulkner \& Madden, 2012; Silverstein and Roszia, 1999). Over the past five years 52\%-58\% of children in public child welfare who left the system via adoption were adopted by their foster parents (U.S. Department of Health and Human Services, 2018). Ryan et al. (2011) found that foster parents often have negative attitudes about openness because of concerns about safety. Despite the misgivings of adoptive parents, Lowe et al. (1999) found benefits to openness including strengthening the child's sense of identity, encouraging attachment to the adoptive parents, and decreased sense of abandonment by their birth/first parents.

Wolfgram's (2008) review of the literature found that overall research on post-adoption openness was framed from a deficit perspective assuming openness was a problem for families. Focusing on factors that contributed to healthy open adoptions, Wolfgram (2008) found face-toface meetings between all configurations of the adoptive family constellation reduced anxiety and increased feelings of control. Thoughtful planning with respect to boundaries and a focus on what would be best for the adoptee's socioemotional development was found to be beneficial.

In the U.S., most of the literature on practitioners and openness examines the prefinalization work preparing adoptive families for formal contact agreements and attitudes about openness from the practitioner perspective (Henney et al., 2003; Neil, 2002; Ryan et al., 2011). 
Henney et al.'s (2003) longitudinal study of adoption agency attitudes towards openness found that agencies increasingly moved toward offering fully disclosed (unmediated by the agency) options for families. Using the Open Adoption Scale (Brown, Ryan \& Pushkal, 2007) and Levels of Openness scale (Maille \& March, 2005), Robinson (2017) found that child welfare workers were generally supportive of open adoptions and did not believe negative myths about openness; however, those who worked in adoptions were more supportive and held less negative beliefs about openness than workers in child protection investigation and foster care (p. 176).

\section{Theoretical frameworks guiding the Inclusive Family Support model (IFSM)}

Three theoretical perspectives guide the development and implementation of the Inclusive Family Support Model (IFSM). Family Systems Theory and the Ambiguous Loss framework provide the foundation for the underlying need for a practice model that helps members of the adoption constellation learn to cope with the ambiguous relationships inherent in adoption, as well as understand the roles of the all family members, including those of the birth/first family. The Transtheoretical model frames the IFSM approach to helping families become more open in spirit and/or in practice.

Family Systems Theory

Family systems theory, attributed to Bowen (1996), developed out of general systems theory and is focused on the ways family members function within the family system. As a basis for family therapy, family systems theory emphasizes the family as a whole rather than any one individual's behavior in isolation. As with any system, a change or movement in one part of the system affects the whole system. Through continuous feedback and a tendency toward equilibrium, a family as a system strives to maintain status quo. Family systems theory is applicable to adoption in several ways. For example, the concept of the triangle, a three-person 
relationship in which two people have a dyadic relationship with a third less-powerful "outsider," is core to family systems theory and recalls the adoption "triad" representing the birth parent, adoptive parent, and adoptee. Another family systems concept, the parental projection of their fears about a child on to the child, is often seen in adoptive families particularly when the child has behavioral or emotional problems. Also, membership is sometimes contested in adoptive families who may not include an adopted child's birth/first family as legitimate members of the family system.

\section{Ambiguous Loss}

As Boss (2007) theorized, ambiguous loss is "a loss that remains unclear" (p. 105). Ambiguous loss was developed to identify the particular stress that comes from managing the relationship with a loved one who is "there, but not there" (emphasis original, p. 105). There are two types of identified ambiguous loss: physical presence with psychological absence, and physical absence with psychological presence (Boss, 2007). An example of physical presence with psychological absence might be when a person has dementia, a mental health or addiction that makes them emotionally unavailable to respond to others seeking their attention. For some adopted children, this type of ambiguous loss may have been present in their pre-adoption relationships with birth/first parents, particularly if their parent's mental health or substance addictions led to neglect of their children.

The type of ambiguous loss that typically resonates with the adoption constellation is where a person is physically absent but psychologically present. Adopted children and birth family members, if not provided with the opportunity to know each other, may worry about the other's well-being or wonder if the other thinks about them, contributing to that "psychological presence." Boss identifies families with more rigid boundaries around family membership as 
potentially likely to have difficulty coping with ambiguous loss; thus, a flexible definition of family that includes birth/first family members could be beneficial to all members of the extended adoptive family constellation.

\section{Transtheoretical Model of Change}

The transtheoretical model (TTM) of change describes the process of how individuals move through different phases or stages when intentionally changing one's behavior (Prochaska \& Diclemente, 1982). Three phases lead up to the individual's attempt at behavior change; precontemplation is the stage where a person is not planning to change their behavior, contemplation marks the stage where a person has an intent to change their behavior but may still be considering their options and/or desire to actually make the change, and finally the preparation stage is the point where a person begins to formulate a plan for making the intended change. Two action stages characterize the implementation of the intended behavior change, including the action stage wherein a person puts into place specific behavior changes, and maintenance, which marks the period of time when a person works to continue the desired behavior change (Prochaska, 2008).

For adoptive parents, the process of increasing openness can be frightening. Many families are likely to stay in the precontemplative phase even if they completed a contact agreement; for example, an adoptive parent may agree to send a letter once a year through the adoption agency or facilitator without considering whether it may be beneficial to consider increase the number of letters, move toward an unmediated delivery, or have in-person visits. Some adoptive parents may contemplate increasing openness but not implement that behavior change, while others may have difficulty maintaining the current level of openness.

\section{Development of Inclusive Family Support Model}


The agency is a child welfare agency on the West Coast of the United States that has been facilitating adoptions for over 90 years. The agency began as a provider of private independent infant adoption and operates largely from private funding; in 2017 government contracts represented only $14.3 \%$ of the agency's revenue (Agency's Annual Report, 2017). In the past ten years the agency's focus has increasingly turned toward foster care licensing and adoption, eliminating the private infant adoption program and work with expectant parents.

The post-adoption services provided through this agency are consistent with independent private adoption agency practices in the U.S. Federal legislation regulates recruitment, licensing, and placement of children in adoptive homes, but most states have limited statutory guidance and/or funding for post-adoption services other than adoption subsidies (Smith, 2014a). Despite their long history of facilitating adoptions, the agency's post-adoption services had been limited to organizing occasional education workshops for adoptive families centered on specific topics of interest to parents and ad hoc problem-solving consultations with adoptive parents who inquire about issues such as; dissolving their adoption or guidance during visits with birth/first families. Prompted by legislative funding changes in 2013 limiting post-adoption resources available through the state's Department of Children, Youth and Families, the agency hired its first Post-Adoption Program manager (now Director) in 2016 to expand the agency’s postadoption services.

The IFSM was developed after conducting a needs assessment through the agency. The needs assessment was conducted over the course of three months and consisted of synthesizing data from an Alumni Family Post-Adoption Survey in 2015, a community forum meeting, monthly consultations with the agency's post-adoption program advisory team, researching local and nationwide agencies and service providers, and a facilitated alumni community meeting. The 
goal of these strategies was to define and analyze post-adoption gaps and to then prioritize the needs. One family focus group that met in July of 2015 noted: "Our child's birth-parents never contacted us. Should our son wish to contact his birth parents we wouldn't know what to do. Or, if they do contact us, what are our rights for visitation? We would have no clue what to do." More than $60 \%$ of the 145 families that attended the community forum reported that their postadoption needs were not being met. The greatest stated needs revolved around the desire for more support when interacting with their children's biological family members. One comment from the survey read; "My daughter is now a teenager and is interested in reconnecting with her birth parents. We could use help figuring out how to approach this.” The IFSM is intended to provide a blueprint for practitioners working to help adoptive families maintain healthy relationships with their children's birth/first parents. Many practitioners within the agency responded to family inquiries without a rubric or evidence-based guidance and thus responses were often guided by opinion, personal bias and good intentions. The IFSM was also developed as a means to begin collecting measurable data at the agency to inform our work and track openness levels within our families and based upon consistent intervention approaches.

\section{Inclusive Family Support Model Categories}

Grotevant's (2000) definition of openness levels provides a useful starting point. We further conceptualize openness as a double-axis continuum wherein the vertical (y) axis represents the adoptee's knowledge about the adoption and the horizontal (x) axis represents contact between the child and the birth/first parents/family (adapted from Holden, 2013). Thus, at one end of the knowledge axis, adopted children might not even know they are adopted and/or the adoption might be sealed while at the other end of the continuum the child might have full knowledge and identifying information about their birth/first parent(s) including names, location, 
full social and medical history, and information about their adoption from the birth/first parent.

On the axis representing contact adopted children might have no contact at all with their birth/first parent(s), mediated contact in which photos and letters may be shared through an intermediary, occasional direct phone calls, email or social media communication, or varying levels of direct face-to-face contact. Or, adoptees and birth/first parents might have occasional visits or, in some cases, spend significant time together such as birthdays, holidays and vacations.

By conceptualizing these different aspects of openness, the adoptive families at the agency can be seen as residing in one of four quadrants that we have named: inclusive, spirit of openness, mediated contact, and closed (Table 1). Figure 1 shows the location of the category types on the axis.

Table 1. Characteristics of openness types

\begin{tabular}{|l|l|}
\hline Types & Characteristics \\
\hline Inclusive Family & $\begin{array}{l}\text { Both the birth/first family members and adoptive family members are } \\
\text { considered extended family, both in contact and openness. The } \\
\text { relationships are child-centered and inclusive. The child is claimed by, } \\
\text { and able to claim, both families. The child does not feel a need to choose } \\
\text { or rank one family over the other and is able to pursue wholeness in their } \\
\text { identity. }\end{array}$ \\
\hline Spirit of Openness & $\begin{array}{l}\text { Adoptive parents employ a "Spirit of Openness." They understand that } \\
\text { direct contact with birth/first family may be impossible or unsafe but } \\
\text { believe all factual information about their child's birth/first family will } \\
\text { help the adoptee process their adoption story and integrate their identity. }\end{array}$ \\
\hline Mediated Contact & $\begin{array}{l}\text { Openness and/or contact aligns with the stipulations in the original } \\
\text { contact or communication agreement. Exchanges of photos, letters } \\
\text { and/or scheduling visits are done confidentially and through a third- } \\
\text { party. Adoptive parents may harbor feelings of guilt, envy, distaste or } \\
\text { superiority about their child's birth/first family, either consciously or } \\
\text { subconsciously. }\end{array}$ \\
\hline Closed & $\begin{array}{l}\text { Very little identifying information is available to the child and there is } \\
\text { no contact. Birth/first parents do not have the ability to impact the status }\end{array}$ \\
\hline
\end{tabular}



a "Spirit of Openness" may be helpful to an adoptee's identity. The adoptive parents feel discomfort discussing birth/first family members/adoption.

Figure 1. Openness categories by quadrant

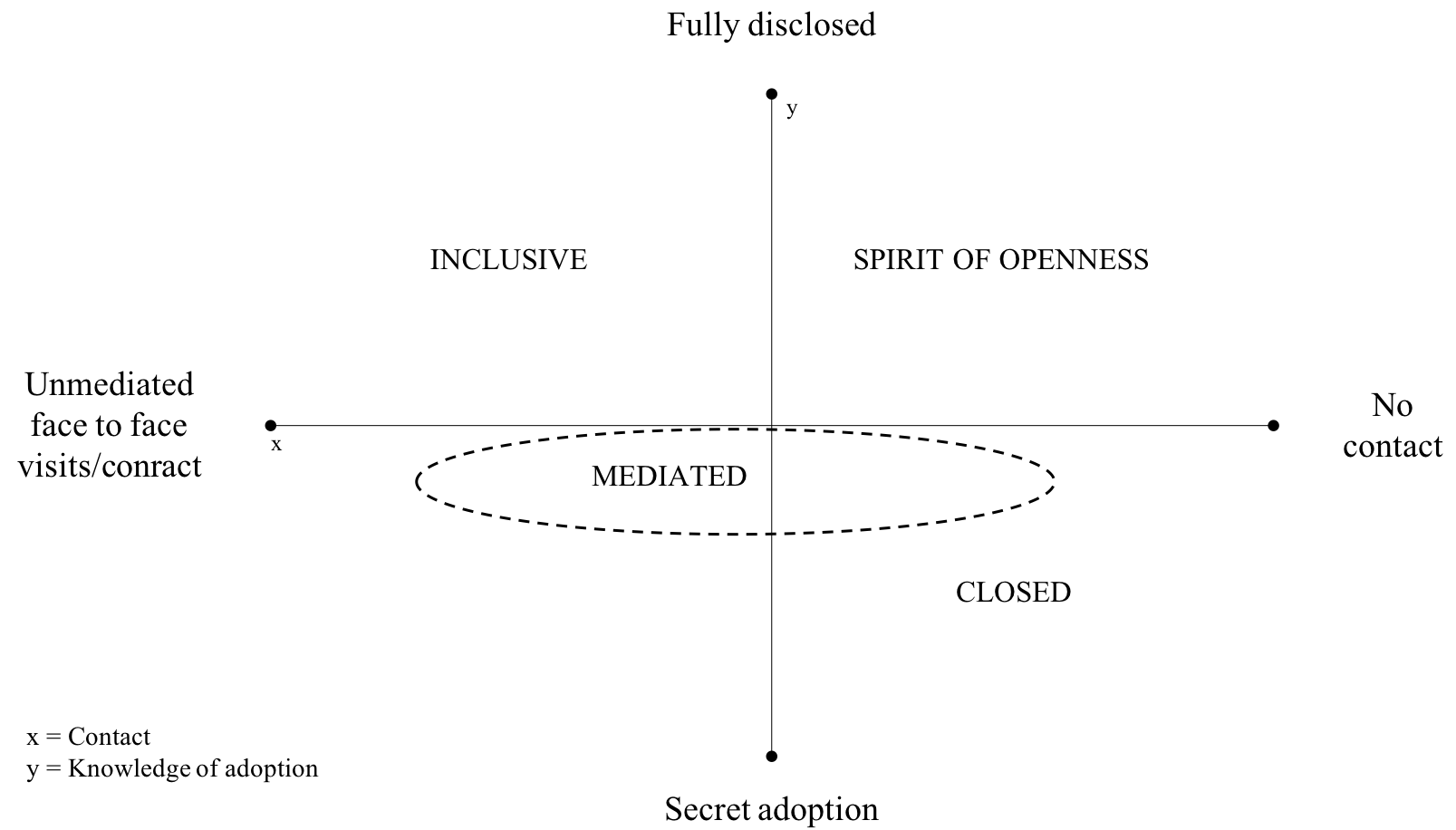

The following vignettes are derived from a composite of the agency's cases. To protect families, names and some details have been altered or changed.

\section{Inclusive}

Jessica is 3 years old and was adopted shortly after her birth. Her adoptive mother, Mary, texts Jessica's birthmother, Sharon, a few times a week. Last week, Jessica learned to hop on one foot. Mary took a video and sent it to Sharon via text message. Mary also invites Sharon over to the home on weekends to have dinner with the family and read Jessica a goodnight story before bedtime. Jessica has been calling Mary "mom," and refers to Sharon as "mama." Sharon is 
grateful to be included in Jessica's life as she states that just because she relinquished her legal rights, does not mean that she should also need to relinquish her love and support for her child. Mary feels strongly that including Sharon into every aspect of their daily lives will allow Jessica to integrate her identity as an adoptee.

\section{Spirit of Openness}

Alicia was born in Haiti just a few days prior to the 2010 earthquake. She was immediately separated from her family, transported to an orphanage, then placed in a foster home. Alicia's adoptive parents, Karla and Ken, have no idea as to the whereabouts of her birth parents. This saddens them deeply as they wish Alicia could know what happened to her first family. They have traveled to Haiti, visited the orphanage, and attempted to locate her foster family. They also conducted a DNA test in an effort to connect with other family members. Karla and Ken feel a genuine curiosity about Alicia's history, and will frequently fold in comments about how she may take after her biological parent(s). For example, they say "You are getting so tall! I wonder how tall your papa was?" Or, "Nice dance moves! The caregivers at the orphanage told us that you were always moving your hips and dancing. It must be in your genes!"

\section{Mediated Contact}

$\mathrm{JJ}$ was adopted his foster parents at the age of 5. Prior to the finalization of the adoption, the Fredrickson's signed a legal Communication Agreement, which outlined the minimum number of visits per year with his birth/first father Malcolm.

The Fredricksons asked the agency to set up a visit between JJ and Malcolm at a public park, reminding the agency worker not to share the make, model or color of their car. Malcolm missed the bus and was ten minutes late. JJ played tag on the playground with Malcolm and 
showed him his new soccer tricks. After the visit, the Fredricksons reported that the visit went okay, but Malcolm smelled of smoke and would terminate all future visits if he arrived smelling like smoke again. They also requested that the agency instruct Malcolm to arrive 30 minutes earlier than the scheduled visit time. Malcolm called the agency thanking the agency for the visit, requesting another visit happen sooner than the Communication Agreement states. The Fredricksons denied this request citing the original agreement, stating "We feel that the two visits a year are more than enough at this point."

\section{Closed Adoption}

Becky was adopted at 8 months old and her adoptive parents changed her birth name in an effort to detach her from the past. For ten years Becky's first/birth mother sent letters through the adoption agency. Becky's parents did not share the letters with Becky. At age 15, Becky has begun to ask questions about her birth/first family and wants to search for her biological family. Becky's adoptive mother calls the agency to ask about how they should proceed.

\section{Inclusive Family Support model process}

The IFSM itself consists of six process steps containing the activities the agency implements with the adoptive family post-finalization (see Figure 2 below). In addition, part of the IFSM process includes assessing the family's openness type and offering continuing case management work based on their openness type.

Figure 2: Inclusive Family Model Process

1.

$$
\int \begin{aligned}
& \text { 30-day } \\
& \text { check in }
\end{aligned}
$$

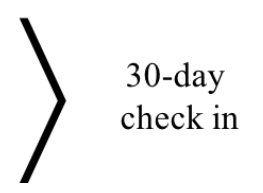

3.
4.

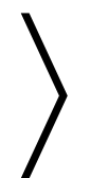

5.

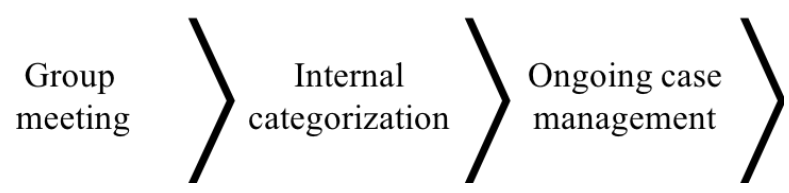


The first stage in the model is to provide a brochure sharing information with families about the post-adoption services the agency offers. For prospective adoptive parents this information ideally would be shared at the time of the adoption finalization. For expectant parents in private adoptions this information would ideally be provided prior to the child's birth. For birth/first parents involved in the child welfare system this information would ideally be shared after the termination of parental rights but prior to signing a communication/contact agreement. In the next stage of the model, the agency will complete an intake form on the family and gather demographic information, such as the family's adjustment to parenting, any changes or challenges the family has experienced since finalization and individual strengths.

The third stage occurs one month after finalization. The agency will check in with the family and re-introduce the agency's post-adoption programs and services. In the fourth stage the family will be invited to participate in post-adoption group meetings. Post-adoption group meetings will provide space for families (separated for birth/first family members and adoptive family members), to participate in facilitated conversations with other recently finalized families. Group meetings are facilitated by a Master's-level clinician with documented adoption-specific competency who will provide the families with information about navigating and maintaining openness as well as other resources and topics pertaining to post-adoption adjustment. During the fifth stage agency staff assess families and identify where they are on the openness axes. In the final stage agencies provide case management to families.

Families in the inclusive family category have already embraced an expanded idea of family composition and do not need help in moving toward increased openness. Likewise, those families in the "Spirit of openness" category are prevented in maintaining physical contact for a variety of reasons, but these families also embrace an inclusive conceptualization of family. 
Therefore, the more intensive case management will be focused on two categories of families: those mediated contact and closed adoption situations.

\section{Transtheoretical model of change with mediated and closed families}

Families in the mediated contact quadrant, as seen in the case vignette, typically have rigid boundaries around the type of contact they are willing to have with birth/first family, exhibited by a resistance to considering increasing openness or feelings of burden with the amount of openness that already exists. The agency's role is to educate and support the family toward a more open relationship (see Table 2).

Table 2. Agency tasks with mediated families

\begin{tabular}{|c|c|c|}
\hline Stage & Definition & Agency Role \\
\hline Precontemplation & $\begin{array}{l}\text { Adoptive family does not intend } \\
\text { to take action in the foreseeable } \\
\text { future and are reliant upon the } \\
\text { agencies' assistance for } \\
\text { communications. They may not } \\
\text { view their behavior as } \\
\text { problematic. }\end{array}$ & $\begin{array}{l}\text { - Education about healthy adoptee } \\
\text { identity development } \\
\text { - Framing visits as a positive and } \\
\text { child-centered experience } \\
\text { - Provide pre and post-visit } \\
\text { consultations }\end{array}$ \\
\hline Contemplation & $\begin{array}{l}\text { Adoptive family begins to } \\
\text { recognize that their attitudes } \\
\text { and/or behaviors impede healthy } \\
\text { identity development for their } \\
\text { child. They begin to consider } \\
\text { the pros and cons of their } \\
\text { continued reliance on the } \\
\text { agency for support. }\end{array}$ & $\begin{array}{l}\text { - Assist family in identifying barriers } \\
\text { and planning solutions when facing } \\
\text { the obstacles } \\
\text { - Encourage and recommend changes } \\
\text { to make during visits }\end{array}$ \\
\hline Preparation & $\begin{array}{l}\text { Adoptive families intend to take } \\
\text { action in the immediate future } \\
\text { based on agency } \\
\text { recommendations. }\end{array}$ & $\begin{array}{l}\text { - Offer referrals for adoption- } \\
\text { competent therapists } \\
\text { - Share information about setting up } \\
\text { private method of establishing } \\
\text { direct contact, yet maintaining } \\
\text { confidentiality } \\
\text { - Introduce family to other families } \\
\text { who are in inclusive relationships } \\
\text { or employ a Spirit of Openness. }\end{array}$ \\
\hline
\end{tabular}




\begin{tabular}{|l|l|l|}
\hline Action & $\begin{array}{l}\text { Families have made specific } \\
\text { overt modifications in initiating } \\
\text { and following through with } \\
\text { direct contact. }\end{array}$ & $\begin{array}{l}\text { Support the families' chosen } \\
\text { method of direct communication } \\
\text { method }\end{array}$ \\
& $\begin{array}{l}\text { Introduce family to adult adoptees } \\
\text { who have a healthy adoptee identity } \\
\text { and are in a closed adoption. }\end{array}$ \\
\hline
\end{tabular}

Mediated families fear the unknown and the protection of the agency as a buffer. The agency's role (see Table 3) is to support families by providing information, resources, and support to families through each of the stages of change.

Table 3. Agency tasks with closed families

\begin{tabular}{|c|c|c|}
\hline Stage & Definition & Agency Role \\
\hline Precontemplation & $\begin{array}{l}\text { Adoptive family does not intend } \\
\text { to take action in the foreseeable } \\
\text { future. They may not see their } \\
\text { behavior as problematic. }\end{array}$ & $\begin{array}{l}\text { Share general information about } \\
\text { available post-adoption support } \\
\text { services } \\
\text { - Invite families to workshops and } \\
\text { adoptive family gathering events } \\
\text { Work to establish a collaborative, } \\
\text { trusting relationship with families }\end{array}$ \\
\hline Contemplation & $\begin{array}{l}\text { Adoptive family begins to } \\
\text { recognize that their attitude } \\
\text { toward openness impedes healthy } \\
\text { identity development for their } \\
\text { child, or has been fielding } \\
\text { questions and concerns from their } \\
\text { child and start to look at the } \\
\text { possibility of opening up the } \\
\text { adoption. }\end{array}$ & $\begin{array}{l}\text { - Assist families in responding and } \\
\text { interpreting their child's questions } \\
\text { about their adoption. } \\
\text { - Support parents by providing } \\
\text { resources about openness and } \\
\text { healthy adoptee identity } \\
\text { development }\end{array}$ \\
\hline Preparation & $\begin{array}{l}\text { Adoptive family intends to } \\
\text { explore connecting with birth/first } \\
\text { family members in the immediate } \\
\text { future and may be taking small } \\
\text { steps toward opening the } \\
\text { adoption. }\end{array}$ & $\begin{array}{l}\text { Introduce family to others who } \\
\text { have moved from a closed } \\
\text { adoption to a mediated adoption } \\
\text { or, if appropriate, introduce } \\
\text { family to others in an inclusive } \\
\text { relationship or families who } \\
\text { employ a spirit of openness. } \\
\text { - Introduce family to adult adoptees } \\
\text { who have a healthy adoptee } \\
\text { identity and are in open adoption }\end{array}$ \\
\hline
\end{tabular}




\begin{tabular}{|l|l|l|}
\hline & & relationships. \\
\hline Action & $\begin{array}{l}\text { Adoptive family inquires about } \\
\text { searching for and connecting with } \\
\text { birth/first family. }\end{array}$ & $\begin{array}{l}\text { Provide information about } \\
\text { searching } \\
\text { Assist the family in setting up a } \\
\text { method for direct contact }\end{array}$ \\
\hline
\end{tabular}

The primary goal for families in closed adoptions is to help parents see the benefit of engaging in adoption conversations on their child's adoptee identity development. The agency's role is to help the adoptive family recognize that small incremental steps could have positive outcomes.

\section{Implications for practice, policy and research}

The IFSM offers both a theoretical framework and practice guidelines aimed at addressing common challenges with post-finalization openness between adoptive and birth/first families, a significant gap in post-adoption services. There is much we do not know about how agencies respond to concerns about openness from members of the adoption constellation and agencies. For example, do social workers follow up with adoptive families who miss their scheduled letters to the birth/first family? If one of the parties moves, how does the agency follow up? Who advocates for the birth/first family if the adoptive family cuts off contact even if it violates the contact agreement? When the second author reunited with her birth/first mother they learned that annual letters and photos that were sent to the agency over two decades, were never picked up by the birth/first mother. Do agencies have protocols in place for these scenarios? Below we outline implications for practice and policy and describe the agency's future research plan for evaluating the ISFM.

\section{Practice}

We argue the IFSM can be used to normalize the questions, concerns and challenges around navigating openness that families face after finalizing an adoption. The model offers 
space to tailor the interactions based on presenting issues. Specifically, post-adoption practitioners are sometimes tasked with "undoing" some of the negative or cautionary messages that adoptive families have received from others including their social worker, guardian ad litem/CASA, judges, and the child's birth/first relatives. These messages are often based in perceived safety concerns which do not necessarily have to impact openness. Practitioners may need to engage in multiple conversations with adoptive families about perceived versus actual safety risks for the child and will need to understand that adoption constellation members may remain in the contemplative phase due to factors such as socioeconomic status, zip codes, race, physical disabilities and/or mental illness. All of these factors impact one's understanding of when situations may feel safe versus actually being unsafe. This is particularly important for families adopting children from the foster care system since research has found that foster care adoptions are less likely to have post-adoption contact agreements (Faulkner \& Madden, 2012) and that foster care workers have more negative perceptions about openness than adoption workers (Robinson, 2017).

The lack of standardized practices for informing all parties about the legal enforceability of contact/communication agreements may lead to gaps in services especially to birth/first families involved in foster care adoptions. If an adoptive family breaches on the contact/communication agreement the onus falls wholly to the birth/first family to take the adoptive family to court. The ongoing and consistent contact with adoptive families via the IFSM enables agencies to have the ability to be involved sooner with adoptive families considering ending contact, which may lessen the potential for a contact/communication breach.

The IFSM aims to shift the focus from adoptive parent-centric feelings to active steps that are adoptee-focused and aimed at strengthening the adoptee's positive identity development. 
Adoptive parents' general and/or specific fears may prohibit openness. For example, a common fear for adoptive parents is that their child will experience divided loyalty and confusion about who the "real parents" are; learning from other families' experiences or from hearing a first-hand perspective from adult adoptees in open relationships would be beneficial in helping adoptive parents imagine how their own family might navigate through a similar scenario. Adoptive parents also frequently fear that their child cannot handle the inevitable emotions that may be present during or after a visit with their birth/first parents. Adoptive parents in the contemplation stage may interpret their child's subsequent acting out behavior as a signal that the visits are not helpful and should not continue; however, regression is a common step towards progress. The IFSM operates with the understanding that open adoptive family relationships will ebb and flow as longitudinal research has confirmed (Grotevant \& McRoy, 1998; Neil, 2009; Siegel, 2012).

Finally, the IFSM allows practitioners to move through the model at a pace that fits with the families' awareness and readiness. If an adoptive parent declines an invitation to a Group Meeting this should not be viewed as a disinterest in openness, but rather an understanding that the family may still be in the precontemplative stage. Practitioners should continue to invite them to the Group Meeting or move to subsequent steps in the model to maintain an open line of communication with the family. As author and practitioner Joyce Maguire Pavao states, "You cannot legislate relationships, they must be built" (J.M. Pavao, personal communication, June 8, 2018).

Policy

Several aspects of the IFSM highlight policy considerations and/or gaps. Consistent policies regulating openness and contact agreements are needed. States vary in terms of dispute resolution and recourse for birth/first families when an adoptive family does not follow through 
with a contact agreement. Some states require mediation, while others do not consider contact. agreements enforceable (Child Welfare Information Gateway, 2014). There are no stated federal policies providing guidance on when or if adoption agencies can reach out to birth/first parents, particularly in the case of foster adoption, in order to provide information about open adoption agreements. There may be a lengthy gap between a termination of parental rights and an adoption finalization and thus, birth/first parents may be difficult to find when the actual contact agreement might be written. Additionally, pre-adoptive parents are often given conflicting advice regarding their obligation or expectation of contact with birth/first families (Neil, 2002).

Establishing agency policies around standardizing practice with families regarding openness both in pre-adoption and post-finalization stages decreases the chance of individual worker bias influencing a family's attitudes and behaviors toward openness.

Research

Evaluating the IFSM is an important next step to validate the model's impact on family and agency outcomes. The agency that developed this model is in the early stages of designing formative and summative evaluations. Important formative questions include training staff to implement the model, administrative tasks related to record-keeping and data tracking of families, and the reflective supervision structure for clinicians. Attitudes of adoption agency workers influence prospective adoptive parent attitudes about openness (Neil, 2002); however, favorable attitudes are not enough to help families navigate openness (Kedward, Luckock \& Lawson, 1999). Although research findings recommend adoption agencies educate prospective parents, rather than prescriptive templates, of what openness should look like (Neil, 2002; Siegel, 2012; Silversteen and Roszia, 1999), families sometimes do not, or cannot, absorb all the 
information in the early stages of adoptive family formation. The evaluation of the ISFM will provide data on the effectiveness of specific ISFM activities.

Wolfgram (2008) approached the body of literature on adoption openness in search of the factors that contribute to healthy, ongoing relationships between birth/first and adoptive parents, but adoptees are not included in this research question. Thus, the adoptee perspective will be included in the evaluation of the ISFM. Understanding behavior and attitude changes regarding openness over time is important (Grotevant and McRoy, 1998; Siegel, 2012). Summative questions include: the increased or decreased beliefs or behaviors of adoptive families related to openness (i.e. less cancellation of visits or increased number of visits); satisfaction of IFSM services, and behavior or attitude changes for the adopted children.

\section{Conclusion}

This article outlined the development of the IFSM as a guide to help adoption agencies work with members of the adoption constellation around post-adoption openness. As child welfare agencies continue to face the reality of increasing demand by the adoption constellation for openness, the IFSM offers an avenue to expand the concept of openness from merely the "letter of the law" to a "spirit" of openness. Open adoption is not merely something parents do when they exchange photos, send emails, or share a visit; rather, openness can be imagined as a lifestyle that may have its ups and downs as all family relationships will. Tensions can arise even in the best of circumstances, and the relationship may be difficult, inconvenient, or even intrusive at times. The ultimate aim, however, is to help the adoptee successfully develop a healthy identity. Withholding key information about an adoptee's own story could impede that development and even erode the adoptee's trust for the adoptive parents. Thus, helping adoptive 
parents learn how to handle situations related to openness for the health of the family system and feeling supported by the agency - particularly for well-being of the adopted child - is paramount.

\section{References}

[Agency] (2017). 2017 Report to our community. Retrieved at [masked for review].

Avery, R. J. (2004). Strengthening and preserving adoptive families: A study of TANF-funded post adoption services in New York State. Retrieved December, 22(2004), 167-191.

Barbanell, L., \& Ryan, S. (2006, July). Openness in adoptions: Comparing adoptive parent and adoptive adolescents' experiences. Paper presented at the 2nd International Conference on Adoption Research, Norwich, England.

Berry, M. (1990). Preparing and supporting special needs adoptive families: A review of the literature. Child and Adolescent Social Work, 7, 403-419.

Berry, M. (1993). Adoptive parents' perception of and comfort with open adoption. Child Welfare, 72(3), 231-253.

Boss, P. (2007). Ambiguous loss theory: Challenges for scholars and practitioners. Family Relations, 56(2), 105-111. DOI: org/10.1111/j.1741-3729.2007.00444.x

Brodzinsky, D. M., \& Schechter, M. D. (1990). The psychology of adoption. Oxford University Press.

Brooks, D., Allen, J., \& Barth, R. P. (2002). Adoption services use, helpfulness, and need: A comparison of public and private agency and independent adoptive families. Children and Youth Services Review, 24(4), 213-238.

Brown, D., Ryan, S., \& Pushkal, J. T. (2007). Initial validation of the Open Adoption Scale: Measuring the influence of adoption myths on attitudes toward open adoption. Adoption 
Quarterly, 10(3-4), 179-196. DOI: doi.org/10.1080/10926750802163246

Bowen, M. (1966). The use of family theory in clinical practice. Comprehensive Psychiatry, 7(5), 345-374. DOI: 10.1016/S0010-440X(66)80065-2

Child Welfare Information Gateway (2014).

Dhami, M. K., Mandel, D. R., \& Sothmann, K. (2007). An evaluation of post-adoption services. Children and Youth Services Review, 29(2), 162-179. DOI: 10.1016/j.childyouth.2006.06.003

Faulkner, M. \& Madden, E. (2012). Open adoption and post-adoption birth family contact: A comparison of non-relative foster and private adoptions. Adoption Quarterly, 15(1), 35-56. DOI: 10.1080/10926755.2012.661333

Feast, J., \& Howe, D. (1997). Adopted adults who search for background information and contact with birth relatives. Adoption \& Fostering, 21(2), 8-15.

Frasch, K., Brooks, D., \& Barth, R. (2000). Openness and contact in foster care adoptions: An eight-year follow-up. Family Relations, 49 (4), 435-446. DOI:

$10.1111 / \mathrm{j} .1741-3729.2000 .00435 . \mathrm{x}$

Freundlich, M., Avery, R. J., Gerstenzang, S., \& Munson, S. (2006). Post-permanency: An assessment for families' needs for services and supports. Journal of Family Strengths, $9(1), 5$.

Grotevant, H.D. \& McRoy, R. G. (1998). Openness in adoption: Exploring family connections. Thousand Oaks, CA: Sage Publications Inc.

Henney, S. M., McRoy, R. G., Ayers-Lopez, S., \& Grotevant, H. D. (2003). The impact of openness on adoption agency practices: A longitudinal perspective. Adoption Quarterly, $6(3), 31-51$. 
Holden, L. (2013, January 12). Open Adoption Grid: Adding a Dimension to the Open Adoption Spectrum [blog post]. Retrieved from https://lavenderluz.com/open-adoptiongrid/.

Kedward, C., Luckock, B., \& Lawson, H. (1999). Mediation and post-adoption contact: the early experience of the Post-Adoption Centre Contact Mediation Service. Adoption \& Fostering, 23(3), 16-26.

Lowe, N., Murch, M., Borkowski, M., Weaver, A., Beckford, V., \& Thomas, C. (1999). Supporting adoption: Reframing the approach. London, UK: British Agencies for Adoption and Fostering.

Miall, C. E., \& March, K. (2005). Open adoption as a family forum: Community assessments and social support. Journal of Family Issues, 26(3), 380-410. doi:10.1177/0192513£04270210.

Neil, E. (2002). Contact after adoption: The role of agencies in making and supporting plans. Adoption \& Fostering, 25-38.

Neil, E. (2009). Post-adoption contact and openness in adoptive parents' minds: Consequences for children's development. British Journal of Social Work, 39(1), 5-23. DOI: 10.1093/bjsw/bcm087

Prochaska, J. O. (2008). Decision making in the transtheoretical model of behavior change. Medical decision making, 28(6), 845-849.

Prochaska, J. O., \& DiClemente, C. C. (1982). Transtheoretical therapy: Toward a more integrative model of change. Psychotherapy: Theory, Research \& Practice, 19(3), 276. DOI: $10.1037 / \mathrm{h} 0088437$

Reilly, T., \& Platz, L. (2004). Post-adoption service needs of families with special needs 
children: Use, helpfulness, and unmet needs. Journal of Social Service Research, 30(4), 51-67. DOI: 10.1300/J079v30n04_03

Robinson, S. (2017). Child welfare social workers and open adoption myths. Adoption Quarterly, 20(2), 167-180. DOI: 10.1080/10926755.2017.1289489

Ryan, S. D., Harris, G., Brown, D., Houston, D. M., Smith, S. L., \& Howard, J. A. (2011). Open adoptions in child welfare: Social worker and foster/adoptive parent attitudes. Journal of Public Child Welfare, 5(4), 445-466. DOI: 10.1080/15548732.2011.599772

Siegel, D.H. (2012). Growing up in open adoption: Young adults' perspectives. Families in Society, 93(2), 133-140. DOI: 10.1606/1044-3894.4198

Smith, S. L. (2014a). Keeping the promise: The case for adoption support and preservation. New York, NY: Donaldson Adoption Institute. Retrieved from https://www.adoptioninstitute.org/publications/keeping-the-promise-the-case-for-adoptio n-support-and-preservation/

Smith, S. L. (2014b). Supporting and preserving adoptive families: Profiles of publicly funded post-adoption services. New York: Donaldson Adoption Institute.

Silverstein, D., \& Roszia, S. (1999). Openness: A critical component of special needs adoption. Child Welfare, 78 (5), 637-651.

Wolfgram, S. M. (2008). Openness in adoption: What we know so far-A critical review of the literature. Social Work, 53(2), 133-142. DOI: https://doi.org/10.1093/sw/53.2.133

Wright, L., Flynn, C. C., \& Welch, W. (2006). Adolescent adoption and the birth family. Journal of Public Child Welfare, 1(1), 35-63.

U.S. Department of Health and Human Services (2018). AFCARS Reports \#21-25. Retrieved from https://www.acf.hhs.gov/cb/research-data-technology/statistics-research/afcars 